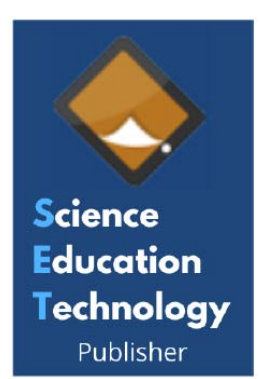

\title{
Impact of Sand Filled Glass Bottles on Performance of Conventional Solar Still
}

\author{
Pankaj Dumka*, Harshit Gautam, Saksham Sharma, Chinmay Gunawat and Dhananjay R. \\ Mishra
}

Department of Mechanical Engineering, Jaypee University of Engineering and Technology, A.B. Road, Guna 473226, Madhya Pradesh, India

\section{Article Info:}

Keywords:

Desalination,

Conventional solar still

Sensible Energy storage,

Sand filled bottles.

\section{Timeline:}

Received: December 09, 2021

Accepted: January 17, 2022

Published: January 21, 2022

Citation: Dumka P, Gautam H, Sharma

S, Gunawat C, Mishra DR. Impact of

Sand Filled Glass Bottles on

Performance of Conventional Solar Still.

J Basic Appl Sci 2021; 18: 8-15.

DOI: https://doi.org/10.29169/1927-5129.2022.18.02

\begin{abstract}
:
Experimental evaluation of conventional solar still (CSS) and CSS with sand-filled glass bottles (Modified solar still (MSS)) have been reported in this article. Two identical CSS were fabricated for the experiments. The experiments were designed and performed under Guna (India) weather conditions in November 2021. Sandfilled glass bottles were paced as sensible energy-storing material. The mathematical model proposed by Kumar and Tiwari has been utilized to evaluate internal heat transfers, internal efficiency, and exergy efficiency. For checking the economic feasibility of sand-filled glass bottle within CSS, a comparative cost analysis has been performed to evaluate CPL (Cost per Litre). It has been observed that the MSS has yielded $21.32 \%$ more than CSS. And overall internal efficiency has also increased by $139.45 \%$ due to the presence of sand-filled glass bottles.
\end{abstract}

${ }^{*}$ Corresponding Author

E-mail: p.dumka.ipec@gmail.com

(c) 2022 Dumka et al.; Licensee SET Publisher.

This is an open access article licensed under the terms of the Creative Commons Attribution License (http://creativecommons.org/licenses/by/4.0/) which permits unrestricted use, distribution and reproduction in any medium, provided the work is properly cited. 


\section{INTRODUCTION}

Rapid industrialization and continuous contamination of natural water resources pose a threat of existential crises for every living creature on this planet. Moreover, with an increasing rate of consumption and demand, we need a source that can bear the burden of providing enough potable water. Solar Still is a device that works on solar energy to cure the current water crisis. Since it works on solar power, so no harm to the environment is caused, it utilizes the immense reservoirs of salty water present on our planet. But this mechanism has its limitations, suffering from low distillate yield and a need for huge surface area and peculiar weather conditions to work correctly.

Various people have contributed to making solar stills a more efficient device in the last few decades [1]. A review on different domestic designs of solar still such as single basin single slope solar still, single basin double slope solar still, hybrid solar still, miscellaneous designs of solar stills has been reported by Yadav et al. [2]. A review on the effect of absorbers, brine depth, flow rate, cover cooling, and still geometry has been reported by Ayoub et al. [3]. Kabeel et al. [4] has written a review on different methods and modifications used to improve productivity such as parameters like thickness and its inclination, atmospheric temperature, the heat capacity of still. A study on performance enhancement of solar still by implementing various heat exchange mechanisms has been performed by Kabeel et al. [5]. The yield of a solar still highly depends on water depth and the initial temperature of water in the basin of still [6].

Dumka et al. [7] augmented solar still with an ultrasonic fogger and reported a $33.26 \%$ higher distillate yield. They have written a $53.12 \%$ higher distillate in MSS with augmentation of ultrasonic fogger and a cotton cloth [8]. They have also reported the overall efficiency of MSS is $44.64 \%$ higher than CSS. Panchal et al. $[9,10]$ have reported fins to increase productivity due to an increase in surface area of water at the basin. Fins have also reduced the bottom and side losses in CSS. They have also reported use of energy-storing material to store heat during the day and release it during the nighttime hours. Experimental and theoretical evaluation with augmentation of jute-covered plastic balls of the conventional solar still has been reported by Dumka et al. [11]. The MSS has yielded $64 \%$ higher than CSS. Also, jute-covered plastic balls have improved efficiency by $32.76 \%$.
The use of sand-filled cotton bags (due to the porous nature of sandbags) to enhance surface area and sensible heat-storing capacity of CSS has been reported by Dumka et al. [12]. Augmentation of sandbags has improved the distillate output and the efficiency of solar still substantially. The use of permanent magnets placed inside conventional solar still has been reported by Dumka et al. [13]. Magnetization of water has resulted in a $49.22 \%$ higher distillate yield in MSS. Improvement in evaporative heat transfer coefficient and partial pressure between water and glass cover has also been observed using magnets. A review of different solar still designs such as basin type, weir type, wick type, and inclined solar still integrated with other solar collector has been reported by Kabeel et al. [14]. The effect of different salt concentrations on passive solar stills performance has still been reported by Dumka and Mishra [13]. Optimum evaporative and convective heat transfer coefficient values are found on $1 \%$ of salt concentration. Therefore, $1 \%$ of salt concentration enhanced the performance of solar still appreciably. Jamil et al. [15] have reported the impact of specific height on solar still performance. Distillate yield is found to improve with a reduction in the specific size of CSS.

The use of wax-filled metallic finned cups by Dumka and Mishra [16] has enhanced distillate output for MSS by $22.44 \%$. Evaporative and convective heat transfer coefficients have improved by $15.63 \%$ and $16.95 \%$, respectively. The internal efficiency of MSS is $24.64 \%$ higher than CSS. Energy and Exergy analysis of novel solar stills for coastal sea area and integrated with sand bed earth has been reported by Dumka and Mishra [17,18]. Sharma et al. [19] have reported the addition of coco peat powder, resulting in a remarkable increase in temperature difference between water and glass cover. Productivity has increased by $30.89 \%$ in MSS, whereas the cost per litre has reduced by $21.126 \%$. Experimental analysis of conventional solar still with a solar-powered fountain has been reported by Dumka et al. [20]. The efficiency of MSS is found to be $26.86 \%$ more than CSS.

From the literature, it is eminent that the performance of CSS with sand as sensible energy in the basin water has been done, but in all the cases, the sand is wet by water. Moreover, the presence of glass within the basin has not been reported in the literature. So, the experiments were designed so that glass bottles increase the energy holding capability of still for 
gradual heat absorption and release. The objective of the current work is to understand the thermodynamic aspect of CSS augmented with sand-filled bottles. In addition to evaluating the economic viability of the stills, cost analysis has also been performed.

\section{EXPERIMENTAL SETUP}

Two identical conventional solar stills were fabricated from FRP of thickness $5 \mathrm{~mm}$ for the present experiment. The vertical height of solar still on higher and lower sides were 64.5 and $19.5 \mathrm{~cm}$, respectively. Both the stills are painted black from the inside to absorb solar radiation better. For the basin, a black painted GI tray of thickness $0.74 \mathrm{~mm}$ and area of $1 \mathrm{~m}^{2}$ was utilized for both stills. A transparent iron glass of thickness $4 \mathrm{~mm}$ with an inclination of $24^{\circ}$ with the horizontal is used to cover solar stills. One of the stills is placed as it is (CSS) whereas, in another solar still, sand-filled glass bottles are placed in a basin tray of modified solar (MSS).

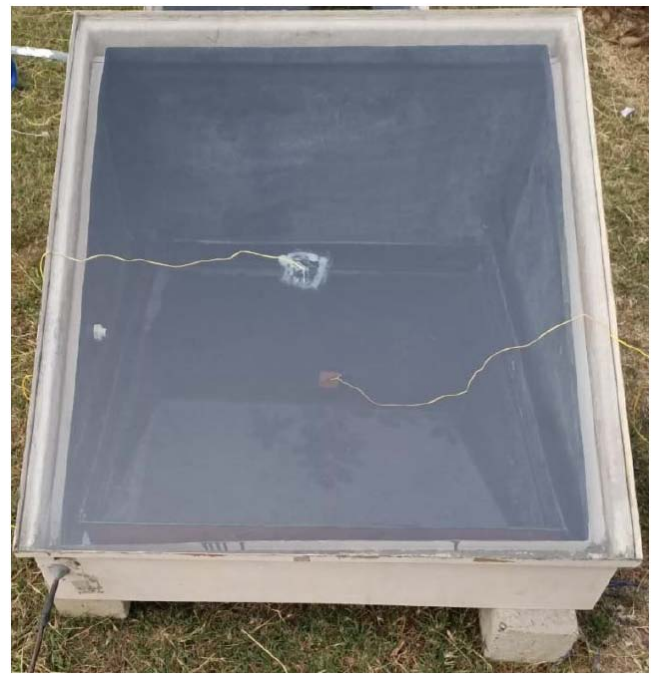

Figure 1: Photograph of CSS.

Glass bottles are cylindrical with a diameter of $25 \mathrm{~mm}$ and a height of $43 \mathrm{~mm}$. A glass bottle weighs $23 \mathrm{gm}$ each is filled with sand up to maximum size. Each sand-filled bottle weighs $38 \mathrm{gm}$. Within the bottles, silica sand of 47 GFN was utilized. A total of a hundred and one bottles were placed in MSS.

Sand-filled glass bottles were placed in an upsidedown position with medical tape wrapped around the cap of every bottle to prevent water from entering the bottle. The purpose of using these sand-filled glass bottles was to utilize the energy gaining capacity of sand and utilize the resistance of glass for sand to hold energy as long as possible.

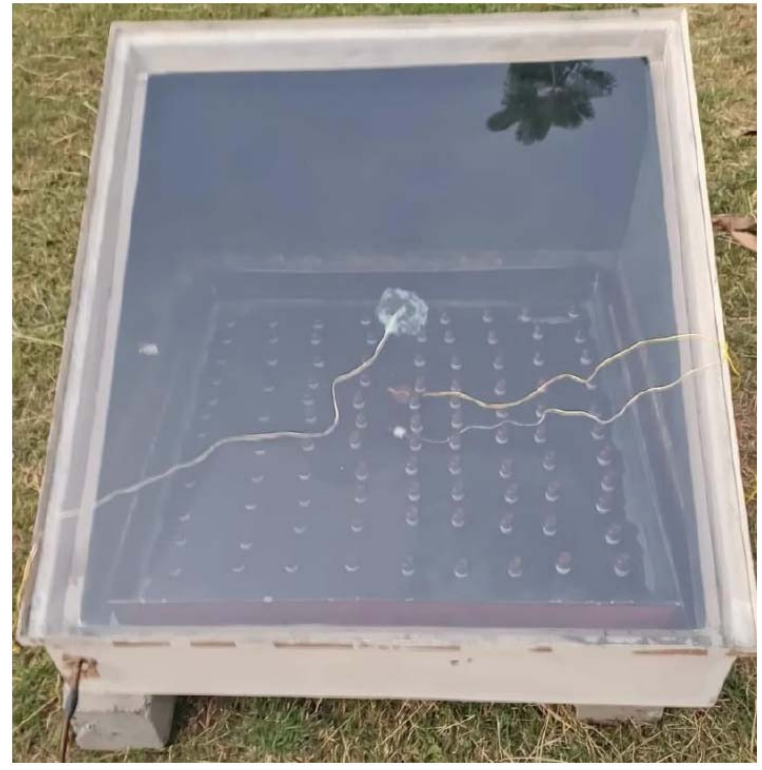

Figure 2: Glass bottles placed inside still (MSS).

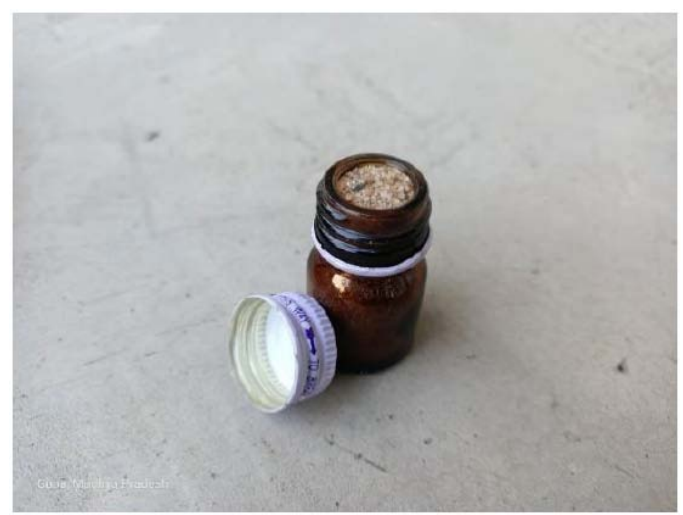

Figure 3: Sand filled glass bottle.

Two K-type thermocouples (K 7/32-2C-TEF) were deployed in CSS to measure inner condensing glass cover and water temperatures. In contrast, three were deployed in MSS for inner condensing glass cover, water and one for measuring the temperature of sand inside the bottle. One additional thermocouple was deployed to measure the ambient temperature. The DTC324A-2 thermal indicator is used to record temperature on an hourly basis. The hourly distillate output is measured with the help of a graduated cylinder. In addition, a solar power meter (TM-207) has been utilized to record solar radiation intensity.

The numerical magnitude of standard uncertainty for different instruments is evaluated with the following formula:

$u=a / \sqrt{3}$

where, $a$ is the accuracy of the instruments. 
Table 1: Measuring Instruments Accuracy, Range and Standard Uncertainties

\begin{tabular}{|c|c|c|c|}
\hline Instrument & Accuracy & Range & Standard Uncertainty \\
\hline \hline Graduated Cylinder & $\pm 1 \mathrm{ml}$ & $0-250 \mathrm{ml}$ & $0.6 \mathrm{ml}$ \\
\hline Thermocouple & $\pm 0.1^{\circ} \mathrm{C}$ & $-100-500^{\circ} \mathrm{C}$ & $0.06^{\circ} \mathrm{C}$ \\
\hline Solar Power meter & $\pm 10 \mathrm{~W} / \mathrm{m}^{2}$ & $0-1999 \mathrm{~W} / \mathrm{m}^{2}$ & $5.77 \mathrm{~W} / \mathrm{m}^{2}$ \\
\hline
\end{tabular}

All the experiments were performed in November 2021 at Jaypee University of Engineering and Technology, Guna, India. The results of experiments were observed and generated on MATLAB 2017b.

\section{THEORETICAL BACKGROUND}

For the distillate output of $\dot{m}_{e w}$ and latent heat of $\mathrm{L}$, the internal efficiency of solar still is given by [17]:

$\eta_{i}=\frac{\dot{m}_{e w} \times L}{I(t) \times A_{s} \times 3600}$

Exergy efficiency is evaluated as [18]:

$\eta_{E X}=\frac{E x_{\text {evap }}}{E x_{\text {in }}}$

Where, evaporation and input exergies expressions are:

$\dot{E} x_{\text {evap }}=A_{s} \cdot h_{e w}\left(T_{w}-T_{c i}\right) \cdot\left[1-\frac{T_{a}}{T_{w}}\right]$

$\dot{E} x_{i n}=A_{S} \cdot I(t)_{s} \cdot\left[1-\frac{4}{3}\left(\frac{T_{a}}{T_{s}}\right)+\frac{1}{3}\left(\frac{T_{a}}{T_{s}}\right)^{4}\right]$

Considering the interest rate (i) and life expectancy of solar still (n) the CRF and SFF for cost analysis are calculated using following equations [11]:

$C R F=\frac{i(i+1)^{n}}{(i+1)^{n-1}}$

$S F F=\frac{i}{(i+1)^{n-1}}$

Here $n$ and $i$ are taken as 15 years and $12 \%$, respectively. Based on the salvage value of salvageable items and the initial investment the ASV and FAC are evaluated as[19]:

$F A C=C R F \times P$

$A S V=S F F \times S$
The annual cost and cost per liter are evaluated as follows [11]:

$A C=F A C+A M C-A S V$

$C P L=\frac{A C}{A Y}$

\section{OBSERVATIONS, RESULTS, AND DISCUSSIONS}

Figure 4 shows the variation of solar radiation intensity to time. Solar radiation recorded at the start of the experiment was $86 \mathrm{~W} / \mathrm{m}^{2}$ at 8:00 h. Which gradually increases to a peak value of $922 \mathrm{~W} / \mathrm{m}^{2}$ at $13: 00 \mathrm{~h}$. From there, it starts decreasing and gets zero at 16:00 $h$ and stays there.

Figure 5 shows the variation of $T_{w}$ for CSS and MSS along with sand-filled glass bottle temperature $\left(T_{s}\right)$ to time. At the start of the experimentation (at 08:00 h), the basin water temperature was $17^{\circ} \mathrm{C}$ and $18.9^{\circ} \mathrm{C}$ for CSS and MSS, respectively. On the other hand, the temperature of sand $\left(T_{s}\right)$ placed inside MSS was recorded as $16.4^{\circ} \mathrm{C}$ at the beginning. As the experiment progresses, CSS attains a peak value of $50.4^{\circ} \mathrm{C}$ at $15: 00 \mathrm{~h}$, whereas maximum $\mathrm{T}_{\mathrm{w}}$ of MSS and $\mathrm{T}_{\mathrm{s}}$ are recorded as $55.3^{\circ} \mathrm{C}$ and $54.3^{\circ} \mathrm{C}$ at $15: 00 \mathrm{~h}$. This is due to the gradual absorption and release of sensible energy by sand filled bottles.

Figure 6 shows the variation of inner condensing cover temperature $\left(T_{\mathrm{ci}}\right)$ of CSS and MSS to time. At 08:00 h $\mathrm{T}_{\mathrm{ci}}$ of CSS and MSS was recorded to be $18^{\circ} \mathrm{C}$ and $17.8^{\circ} \mathrm{C}$, respectively. As the experiment progresses, $\mathrm{T}_{\mathrm{ci}}$ attains a peak value of $43.6^{\circ} \mathrm{C}$ for CSS (at 15:00 h) and $46.1^{\circ} \mathrm{C}$ for MSS. Overall the inner condensing cover of MSS is at a higher temperature than CSS due to the high rate of condensation in MSS, which has led to more release of latent heat of condensation.

Variation of distillate yield of CSS and MSS based on hourly observation is shown in Figure 7. MSS leads CSS throughout the experiment, and a total net gain of 1.046 litres and 1.269 litres was recorded from CSS and MSS, respectively. An overall improvement of 


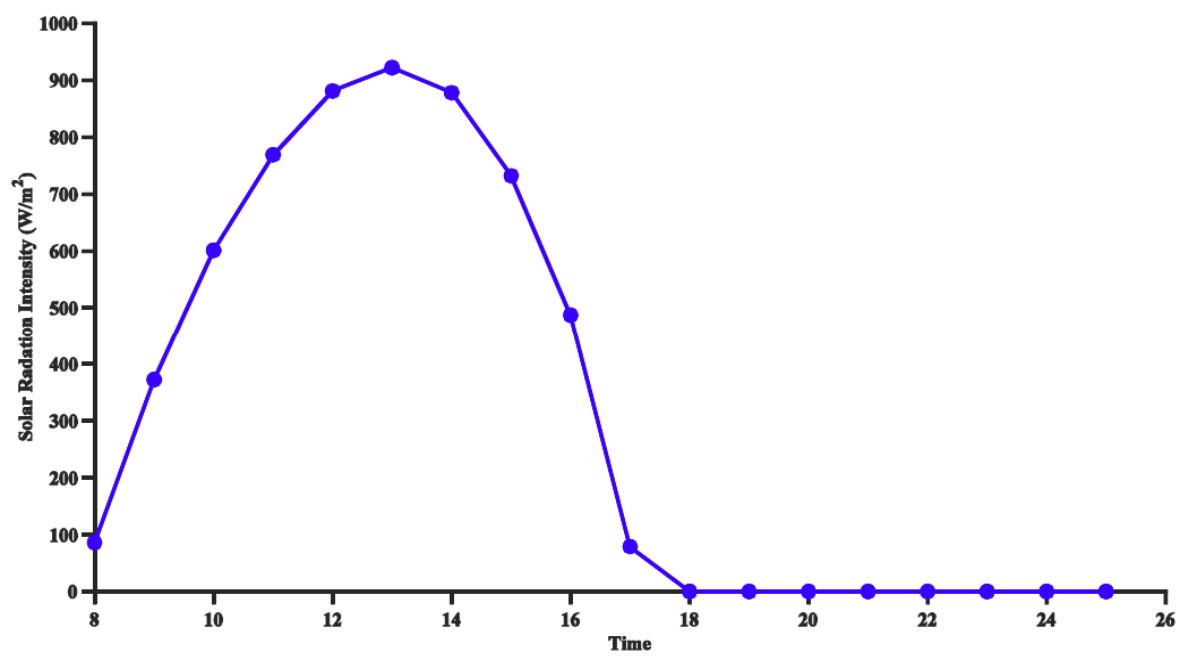

Figure 4: Variation of $I(t)$ as a function of time.

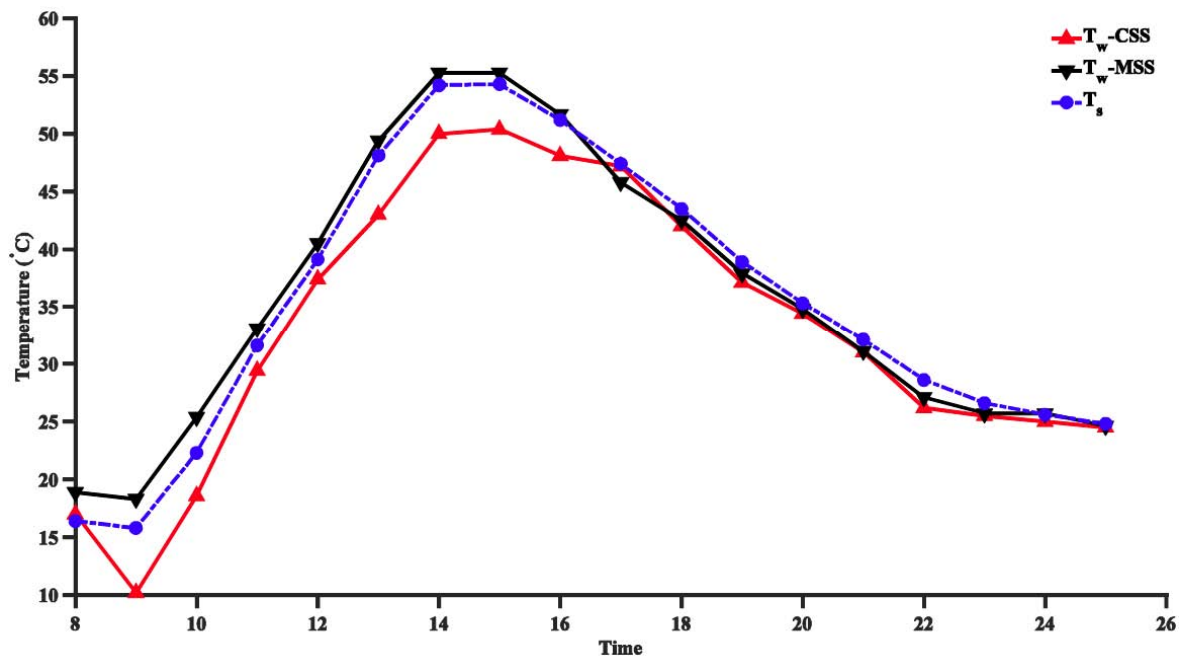

Figure 5: Variation of basin water temperature and sand temperature.

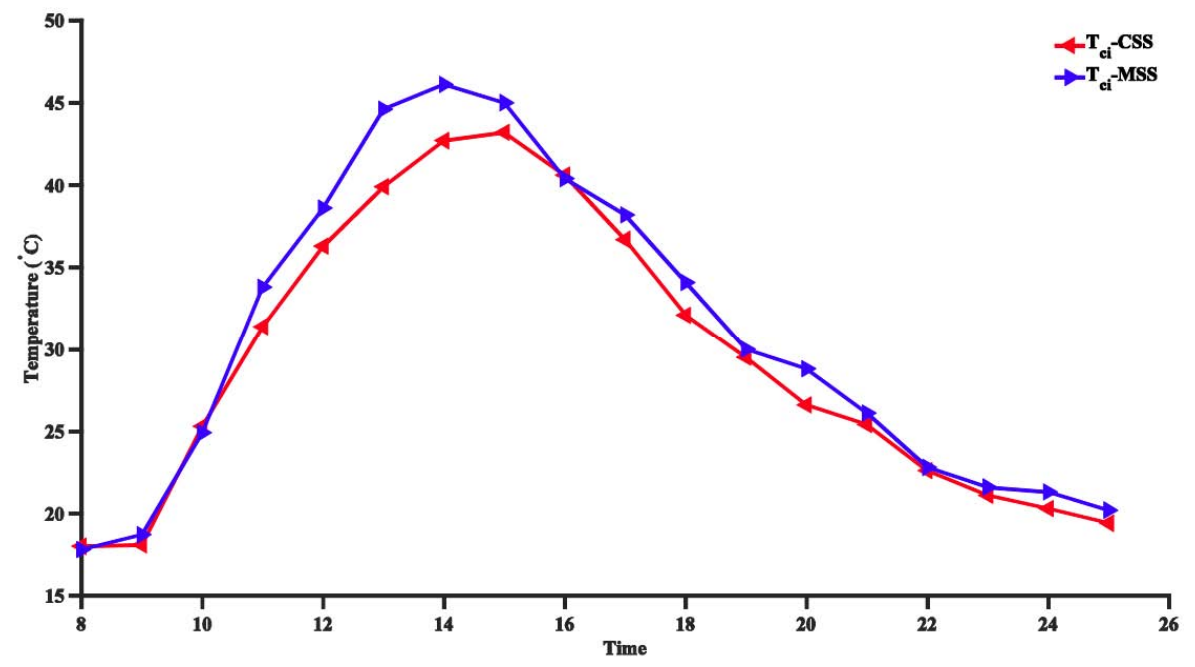

Figure 6: Variation of glass cover temperature as a function of time. 


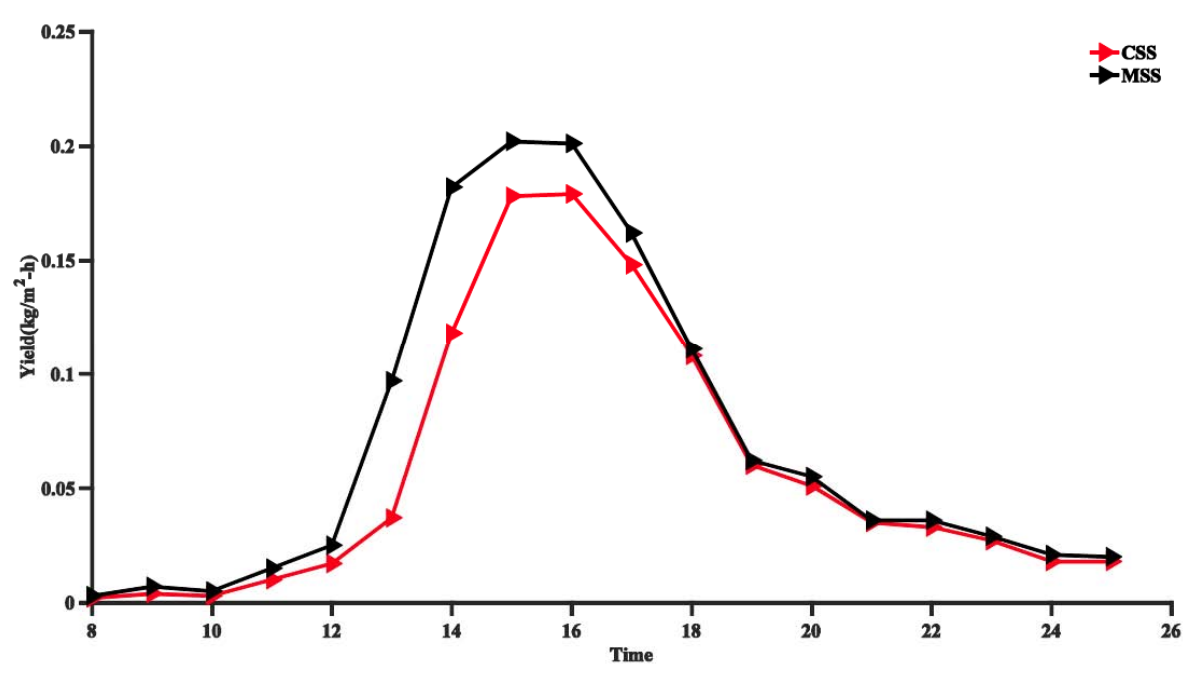

Figure 7: Distillate output variation as a function of time.

$21.32 \%$ has been observed in total cumulative yield due to sensible heat absorption and release by augmentation of sand-filled glass bottles.

Variation of CSS and MSS efficiency is shown in Figure 8 to time. Data until 16:00 h has been utilized to compute the following result: solar radiation intensity decreases at a much faster rate than yield, resulting in impractical results. MSS and CSS, respectively, have observed the overall efficiency of $22.7047 \%$ and $9.4820 \%$. The overall efficiency of the modified still has increased by $139.45 \%$ by placing sand-filled glass bottles.

Figure 9 shows the variation of exergy efficiency ( $\left.\eta_{E X}\right)$ to time. The use of sand-filled glass bottles has increased $\eta_{E X}$ of MSS by $56.415 \%$ compared to CSS. As exergy efficiency is the accurate indicator of performance, it is eminent that the sensible energy gained by the bottles is gradually released. Hence, the water is maintained at elevated temperatures for a long hour in MSS.

Table 2 shows the total expense used to create the CSS and MSS. Additionally, salvage costs are acquired before the finish of the experiment, though Table 3 . Shows, generally different variables that have been determined, show the effect of glass bottles loaded up with sand kept in CSS shows a reduction of $15.29 \%$ in the cost per litre.

\section{CONCLUSION}

Execution of CSS and MSS is explored tentatively in November 2021. A sum of 101 glass bottles loaded with sand is put in MSS. Based on trial results, the accompanying ends are drawn:

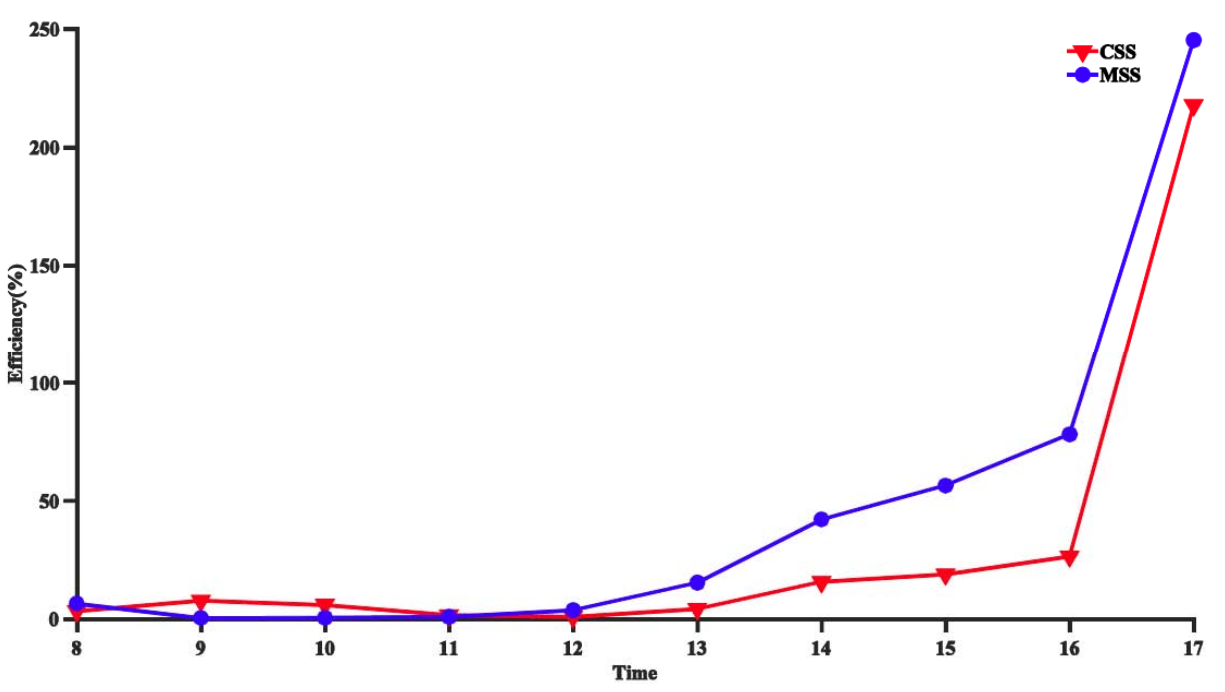

Figure 8: Internal efficiency variation as a function of time. 


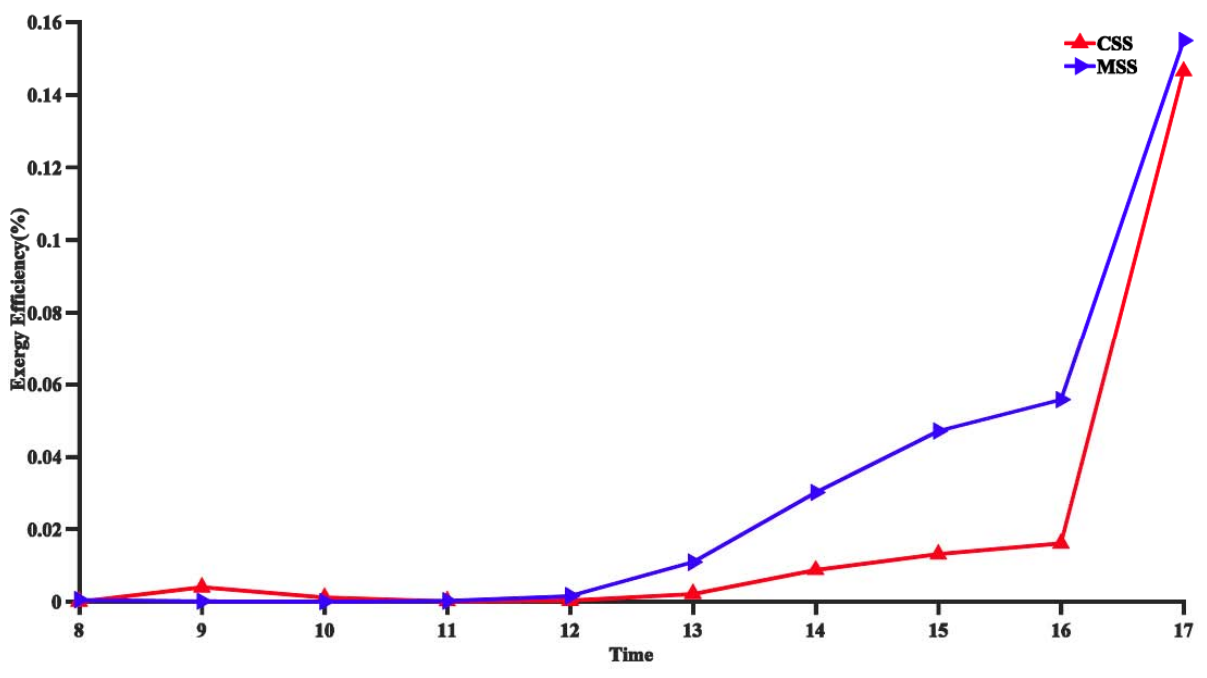

Figure 9: Variation of exergy efficient as a function of time.

Table 2: Installation Cost and Salvage Value of Different Components of CSS and MSS (in Rs.)

\begin{tabular}{|c|c|c|c|}
\hline & CSS & MSS & S \\
\hline \hline FRP Solar Still & 6000 & 6000 & 600 \\
\hline Glass & 500 & 500 & 0 \\
\hline Putty & 100 & 100 & 0 \\
\hline Glass Bottles & - & 100 & 100 \\
\hline Total Cost & 6600 & 6700 & 700 \\
\hline
\end{tabular}

Table 3: Values of Different Cost and Factors for CSS and MSS

\begin{tabular}{|c|c|c|}
\hline & CSS & MSS \\
\hline \hline CRF & 0.1468 & 0.1468 \\
SFF & 0.0268 & 0.0268 \\
FAC & $969.040 \mathrm{Rs.}$ & $983 \mathrm{Rs.}$ \\
ASV & $16.0945 \mathrm{Rs.}$ & $18.7770 \mathrm{Rs.}$ \\
AMC & $145.3560 \mathrm{Rs}$. & $147.5584 \mathrm{Rs}$. \\
\hline AC & $1098.3 \mathrm{Rs}$. & $1112.5 \mathrm{Rs}$. \\
\hline AY & 239.6600 & 286 \\
\hline Total Cost & $4.5827 \mathrm{Rs} . / \mathrm{I}$ & $3.8820 \mathrm{Rs} . / \mathrm{I}$ \\
\hline
\end{tabular}

- Because of the energy holding extent of sand potency of MSS has demonstrated strikingly.

- Improvement in distillate yield by $21.32 \%$ is seen in MSS because of sand filled glass bottles.

- The efficiency of $22.7047 \%$ is seen on account of MSS, though the efficiency of CSS is seen to be $9.4820 \%$.
- A noteworthy increment of $139.45 \%$ is seen in the efficiency of MSS in contrast with CSS.

- $\quad \mathrm{CPL}$ of MSS is viewed as $3.8820 \mathrm{Rs} . / \mathrm{l}$, while CPL of CSS is obtained as $4.5827 \mathrm{Rs} . / /$.

\section{NOMENCLATURE}

$$
\begin{aligned}
& \text { a } \quad=\text { measuring instrument uncertainty } \\
& A_{s} \quad=\text { evaporation area }\left(\mathrm{m}^{2}\right) \\
& \dot{E} x_{\text {evap }} \quad=\text { exergy output of soar still (W) } \\
& \dot{E} x_{i n} \quad=\text { radiation exergy input }(\mathrm{W}) \\
& I(t) \quad=\text { incident solar radiation on inclined cover } \\
& \text { surface }\left(\mathrm{W} / \mathrm{m}^{2}\right) \\
& \mathrm{T}_{\mathrm{ci}}=\text { inner glass cover temperature }\left({ }^{\circ} \mathrm{C}\right) \\
& \mathrm{T}_{\mathrm{w}} \quad=\text { temperature of water surface }\left({ }^{\circ} \mathrm{C}\right) \\
& \mathrm{u} \quad=\text { standard uncertainty } \\
& \sigma=\text { Stefan Boltzmann constant }(\mathrm{W} / \mathrm{m} 2-\mathrm{K} 4) \\
& \dot{m}_{e w} \quad=\text { distillate output }\left(\mathrm{kg} / \mathrm{m}^{2} \mathrm{hr}\right) \\
& \eta_{i} \quad=\quad \text { instantaneous thermal efficiency } \\
& \eta_{E X} \quad=\text { exergy efficiency of solar still }
\end{aligned}
$$

\section{ABBREVIATIONS}

$$
\begin{aligned}
& \text { CSS }=\text { conventional solar still } \\
& \text { FRP }=\text { fibre reinforced plastic }
\end{aligned}
$$




$$
\begin{aligned}
& \mathrm{GI}=\text { galvanized iron } \\
& \text { MSS }=\text { modified } \text { solar } \text { still } \\
& \text { AC = annual cost (Rs.) } \\
& \text { AMC = annual maintenance cost (Rs.) } \\
& \text { ASV = annual salvage value (Rs.) } \\
& \text { AY = annual yield (I) } \\
& \text { CFD }=\text { computational fluid dynamics } \\
& \mathrm{CPL}=\text { cost per liter (Rs./I ) } \\
& \mathrm{CRF} \quad=\text { capital recovery factor } \\
& \text { CSS = conventional solar still } \\
& \text { FAC = first annual cost (Rs.) } \\
& \text { FRP = fiber reinforced plastic } \\
& \text { GI = galvanized iron } \\
& \text { GFN = Grain Fineness Number } \\
& \text { MSS = modified solar still } \\
& \text { Rs = Indian national rupee (1\$=73.69 Rs.) } \\
& \text { SFF } \quad=\text { sinking fund factor }
\end{aligned}
$$

\section{REFERENCES}

[1] Tiwari AK, Tiwari GN. Effect of Cover Inclination and Water Depth on Performance of a Solar Still for Indian Climatic Conditions. J Sol Energy Eng 2008; 130: 024502. https://doi.org/10.1115/1.2844450

[2] Yadav S, Sudhakar K. Different domestic designs of solar stills: A review Renew. Sustain. Energy Rev 2015; 47L 71831. https://doi.org/10.1016/j.rser.2015.03.064

[3] Ayoub GM, Malaeb L. Developments in solar still desalination systems: A critical review. Crit Rev Environ Sci Technol 2012; 42: 2078-112. https://doi.org/10.1080/10643389.2011.574104

[4] Kabeel AE, El-Agouz SA. Review of researches and developments on solar stills. Desalination 2011; 276: 1-12. https://doi.org/10.1016/j.desal.2011.03.042

[5] Kabeel AE, Omara ZM, Essa FA, Abdullah AS, Arunkumar T. Augmentation of a solar still distillate yield via absorber plate coated with black nanoparticles Alexandria. Eng J 2017; 56: 433-8. https://doi.org/10.1016/j.aej.2017.08.014

[6] Tiwari GN, Madhuri. Effect of water depth on daily yield of the still. Desalination 1987; 61: 67-75. https://doi.org/10.1016/0011-9164(87)80007-3
Dumka P, Mishra DR. Performance evaluation of single slope solar still augmented with the ultrasonic fogger. Energy 2020; 190.

https://doi.org/10.1016/j.energy.2019.116398

[8] Dumka P, Jain A, Mishra DR. Energy, exergy, and economic analysis of single slope conventional solar still augmented with an ultrasonic fogger and a cotton cloth. J Energy Storage 2020; 30. https://doi.org/10.1016/j.est.2020.101541

[9] Panchal H, Mohan I. Various methods applied to solar still for enhancement of distillate output. Desalination 2017; 415: 7689.

\section{https://doi.org/10.1016/j.desal.2017.04.015}

[10] Panchal H, Patel DK, Patel P. Theoretical and experimental performance analysis of sandstones and marble pieces as thermal energy storage materials inside solar stills. Int J Ambient Energy 2018; 39: 221-9. https://doi.org/10.1080/01430750.2017.1298059

[11] Dumka P, Chauhan R, Mishra DR. Experimental and theoretical evaluation of a conventional solar still augmented with jute covered plastic balls. J Energy Storage 2020; 32: 101874. https://doi.org/10.1016/j.est.2020.101874

[12] Dumka $P$, Sharma A, Kushwah $Y$, Raghav AS, Mishra DR. Performance evaluation of single slope solar still augmented with sand-filled cotton bags. J Energy Storage 2019; 25: 100888. https://doi.org/10.1016/j.est.2019.100888

[13] Dumka P, Mishra DR. Influence of salt concentration on the performance characteristics of passive solar still. Int $\mathrm{J}$ Ambient Energy 2019. https://doi.org/10.1080/01430750.2019.1611638

[14] Kabeel AE, Khairat MM, Ramzy K, Nabil T, Elnaghi B. Enhancement of single solar still integrated with solar dishes: An experimental approach. Energy Convers Manag 2019; 196: $165-74$. https://doi.org/10.1016/j.enconman.2019.05.112

[15] Jamil B, Akhtar N. Effect of specific height on the performance of a single slope solar still: An experimental study. Desalination 2017; 414: 73-88. https://doi.org/10.1016/j.desal.2017.03.036

[16] Dumka P, Mishra DR. Experimental investigation and thermal analysis of a double slope long still: study of heat and mass transfer. Int J Ambient Energy 2020; 1-9. https://doi.org/10.1080/01430750.2020.1818128

[17] Dumka P, Mishra DR. Energy and exergy analysis of conventional and modified solar still integrated with sand bed earth: Study of heat and mass transfer. Desalination 2018; 437: 15-25. https://doi.org/10.1016/j.desal.2018.02.026

[18] Dumka P, Mishra DR. Experimental investigation of modified single slope solar still integrated with earth (I) \&(II):Energy and exergy analysis. Energy 2018; 160: 1144-57. https://doi.org/10.1016/j.energy.2018.07.083

[19] Sharma S, Rathor R, Gautam H, Katiyar K, Gunawat C, Dumka P. Influence of Coco Peat Powder on the Solar Still Productivity: An Exergo-Economic Study IOP. Conf Ser Earth Environ Sci 2021; 795. https://doi.org/10.1088/1755-1315/795/1/012012

[20] Dumka P, Sharma S, Gautam H, Gunawat C. Impact of Solar Powered Fountain on The Performance of Conventional Solar Still. Int J Eng Res Technol 2021; 10: 109-12. 